\title{
Evaluation in Component Technology Small Scale Food Industry Cluster in West Sumatera
}

\author{
Gunarif Taib $^{\#}$, Santosa ${ }^{\#}$, Masrul Djalal ${ }^{\#}$, Helmi* \\ \# Faculty of Agricultural Technology, Andalas University, Kampus Limau Manis, Padang,Indonesia \\ E-mail: gunariftaib@yahoo.com
}

* Faculty of Agriculture, Andalas University, Kampus Limau Manis,Padang, Indonesia

\begin{abstract}
The development of small-scale food industry cluster is influenced by the technology component. Because it required accurate information about the importance of existing technology components. This study aims to evaluate the technology components that are known several important factors that need to be improved so that clusters of small-scale food industries can thrive. This research using the program Analytic Hierarchy Process (AHP) to determine the level of importance of each variable based on its value. The survey results revealed that each technology component has a value as follows: technoware component of the operation of the order is a factor $(\mathbf{0 . 2 8 8 9})$, quality of raw materials $(0.2770)$, improvement of production efficiency $(0.1894)$, the fulfillment of production capacity $(0.1717)$, technology adoption $(0.0489)$ and resource technologies $(0.0242)$. Components of the order value is organoware environmental management factor $(0.6267)$, marketing management $(0.2797)$ and production management (0.0936). Components infoware order value is a factor of production records $(0.6267)$, the promotion of products $(0.2797)$ and documentation effort (0.0936). Humanware component order is the motivation factor $(0.5022)$, the trust fellow members $(0.1883)$, knowledge manager $(0.1854)$, the management skills $(0.0817)$ and innovation $(0,0425)$.
\end{abstract}

Keywords - Component Technology; Cluster; Food; Small Scale; Analytic Hierarchy Process

\section{INTRODUCTION}

Indonesia has been familiar with the concept of Small Industries and Environment Industry since 1979. Industrial Growth Centre grow through planning and government involvement, while small industrial environment grows naturally. The concept was originally developed to foster small industry for the better, in terms of cost. In the mid1990s, a number of departments also developed the concept of cluster-based industrial development. In fact, there is a department which has published an inventory of the number of potential clusters, i.e clusters that have the potential to develop well [7].

Ministry of Industry directs the development of the industry through the industry cluster approach. For it has been made Map Guide (Road Map) Industrial Cluster Development for 2010 - 2014 is used as a reference guide the development of industrial clusters in order to achieve the growth target of 7 percent per year and as a basis for making Indonesia the Country Tough Industry in 2025 [3]. Because the government has set the industry development through cluster approach, and some of the advantages of industrial clusters for the development of small-scale food industry needs to be done with the cluster approach. In West Sumatra, the formation of industrial clusters, especially for small-scale food industries, among others, performed in the form of business groups joined in the "Service Unit and the Development of Agricultural Product Processing". Until the year 2013, has formed 125 groups scattered throughout the business district / town in West Sumatra [5]. Development of small-scale food industries in West Sumatra is intended to increase the value-added agricultural products. However, until now the cluster is not well developed because they still have problems ranging from procurement of raw materials, processing up on marketing.

In terms of technology, the industry is still faced with the limitations of small to provide appropriate technology and provide significant added value and ready for use. This leads to the high dependence on foreign technology for the processing of agricultural products, thus adversely affects the productivity, efficiency and relative income agribusiness and agro-industries. The last few years business development including small-scale agro-industry is strongly influenced by technological innovation. Special efforts need to have a very small scale in the production specification and select the right technology to be developed in an attempt [4]. For example, the contribution for each component of the 
Small Industries metal technology are: technoware contribution to the coefficient of $32.5 \%$ Component Technology; humanware contribution by $20 \%$; contribution of $25 \%$ infoware components; or contribution organoware component by $25 \%$. Conceptual model of the development of small and medium-sized industries that proposed policies lead to the strengthening of technological development in the industry was small in order to have competitiveness in the global era, the priority order of the components technoware, orgaware, infoware, and humanware. Thus it is expected that Small Industries can maintain the domestic market, and produce a quality product with a touch of technology [9]. Component technology influence the development of clusters. Several influential technology components are as follows: (1) Humanware knowledge, skills and willingness of food processing industry in the production. Also needed innovation to produce new products / new product development. (2)Technoware. That need to be observed is the equipment / machinery used, especially about efficiency and productivity in producing a variety of processed food products. (3)Organoware. Associated with managerial factors in production. It needs to be observed production management. Observations begins with raw materials management, production management and marketing management. (4) Infoware. All production activities must be documented. In the food processing industry to observe existing documentation such as records of raw materials used, processing is carried out until the sales records. This information is necessary for sustainable business.

To accelerate the development of small-scale food industry cluster needs to be evaluated components of any technology that will affect the growth of the cluster. The results of this evaluation are used to plan the development of small-scale food industry cluster in West Sumatra.

\section{MATERIALS AND METHODS}

Research conducted on clusters of small-scale food industries. Industry cluster is selected cultivate food crops seeded in the region. Determination of food commodities to be studied were calculated using Location Quation (LQ). Commodities were selected that has a value of $L Q \geq 1$, and selected that have the highest value. Determination of the district / city that became centres of production are determined based on the value obtained. Initial information about the technology component is obtained through the study of literature. Primary data were collected based on focus group discussions (FGDs) were conducted in the study area. As a source of information used in this discussion several experts and stakeholders who understand the development of small-scale food industry cluster. FGDs were conducted to find the important parameters on each component of the technology that will affect the development of small-scale food industry cluster. Parameters obtained through FGDs were analyzed using the program Analytic Hierarchy Process (AHP) to determine the level of importance of each variable based on its value. Each parameter on each component of the technology is tested in pairs. In this test parameters see which is more important. The level of interest is determined based on the scale of importance. Hierarchical structure of the data analysis and data decisions questionnaire results (using the results of pairwise comparison) was performed by using a mathematical formula in the analytic hierarchy process and aid package AHP program. The data were processed to determine the consistency index and consistency ratio matrix individual opinion.

If the opinion of the individual is not consistent, then the revised opinion. Individual opinion consistent matrix used in preparing the combined matrix was performed again after the data processing system resulting priority vector for each alternative [8].

In this analysis of the various parties involved such as managing clusters of small-scale food industries, government agencies supervising, energy practitioners and consumers. AHP program is used to determine the level of importance of each parameter on the component technologies. The results serve as a recommendation to accelerate the development of small-scale food industry cluster.

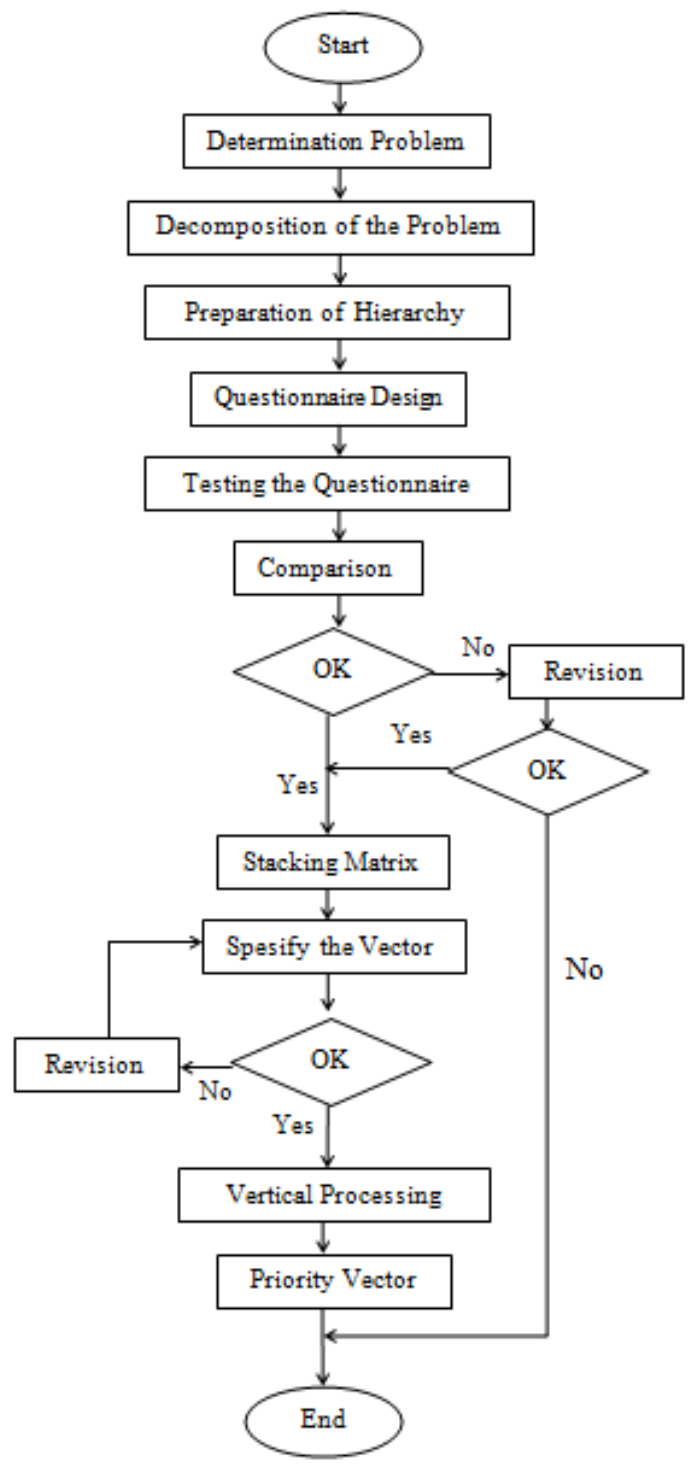

Fig 1. Analytic Hierarchy Process Flow Diagram in Research 


\section{RESULTS AND DISCUSSION}

A study of small-scale food industry cluster in West Sumatra shows some important conditions. Many leading commodity that is processed on a small industrial cassava. These commodities processed by most small-scale food processing industries in West Sumatra. This commodity is seeded apart from the production lot number, other dairy products are also very diverse. In addition, consumers are also very fond of processed products made from raw cassava.

To cultivate cassava does not require difficult processing technology. However, the technology continues to be the deciding factor in the success of small-scale food industries in West Sumatra. In technoware components, machine operation becomes a very important factor with a value of 0.2889 . This shows that the small-scale food industries in West Sumatra Operations tool should be a major concern in the development of the processing industry. Generally processing business owners prioritize the use of appropriate tools. The right tool is in addition easy to operate also easy in maintenance and repair. In addition, the tools used are generally also be multi-function. Such as a drying (dryer) is used for several different commodities. So also other equipment such as a chopper (slicer) is also commonly used for some of commodity such as cassava, taro, sweet potato and so on.

Organoware very important component is the environmental management with a value of 0.6267 . This becomes important because most small businesses have not noticed aspects of the environment. This condition is seen from several things such as cleanliness work environment and waste management. Location processing is still not clean and not well ordered, this resulted in a product that is produced is not of good quality. Waste processing results have not been properly addressed so that generally accumulate in the vicinity of the processing. Besides resulting in the appearance of the business location that is not clean, it would be a waste pile one source of contaminants to the product produced. A very important parameter in infoware component is recording production with a value of 0.6267 . This is important because most of the small-scale food industries in West Sumatra production records have not done well. With these conditions it is difficult to do small business enterprise development because it does not know exactly the condition of their business economically. Planning also can not be done because there is no quantitative data on production that has been done.

Human ware most important components is motivated entrepreneur with a value of 0.5022 . This has become one of the causes of the difficulty of small industries is growing. Generally, these entrepreneurs are too easily satisfied due to lack of motivation in trying. Business management is only done by habit without any motivation to be better developed.

Four important factors in the technology component shows that the small-scale industry, which produces food specially very close to a small community, but it is still far from professionalism. In addition, the continuity of its business is still limited because it is not managed properly. For that we need to create resilient rural entrepreneurs to develop the food industry. Entrepreneurship requires courage and fighting spirit in trying. It also calls for freedom, creativity, and discipline in entering the competition very competitive market. Under certain conditions of social conditions will affect the business world [2].

Competitiveness of businesses in developing countries are affected environmental conditions and infrastructure conditions. Of the important factors in component technology is also seen the importance of quality human resources. Improving the competitiveness of the business relating to the quality of human resources, among others, is the improvement of the business environment, the improvement of the institutions that support clusters, create specific products, improving infrastructure, improving education, and increase human resources related to community services [10]. By improving the quality of human resources is the productivity of small-scale industrial clusters could be increased

Strong cluster of small industries with suppliers of materials and capable of supporting institutions that can improve the productivity of the company. The synergy between the companies will improve the condition of the cluster and the business environment. Thus the cluster development with regard to the success of companies and communities that exist in the cluster [11]. In addition, changes in the number and size of the cluster core businesses needed to adapt to changes in the market and efforts to increase the capacity of the production process through innovation and technology. With this change, the cluster becomes more economical [1].

All efforts to improve the quality of small-scale food industry cluster is in need of the role of government. Since the development of the cluster is affected by government policies, particularly those related to the cost of production. In addition, the low bargaining power producers caused by the marketing monopoly will lower the rate of profit [6].

TABLE I

Parameter VAlue Component Technology

\begin{tabular}{|c|c|c|c|}
\hline No & $\begin{array}{l}\text { Component } \\
\text { Technology }\end{array}$ & Parameter & Value \\
\hline \multirow{6}{*}{1} & \multirow{6}{*}{ Technoware } & Operational Equipment & 0.2889 \\
\hline & & Quality of Raw Materials & 0.2770 \\
\hline & & Increased Production Efficiency & 0.1894 \\
\hline & & Fulfillment Production Capacity & 0.1717 \\
\hline & & Technology adoption & 0.0489 \\
\hline & & source of Technology & 0.0242 \\
\hline \multirow{3}{*}{2} & \multirow{3}{*}{ Organoware } & Environmental management & 0.6267 \\
\hline & & Marketing management & 0.2797 \\
\hline & & Production Management & 0.0936 \\
\hline \multirow{3}{*}{3} & \multirow{3}{*}{ Infoware } & Production records & 0.6267 \\
\hline & & promotional Products & 0.2797 \\
\hline & & documentation effort & 0.0936 \\
\hline \multirow{5}{*}{4} & \multirow{5}{*}{ Humanware } & motivation & 0.5022 \\
\hline & & Fellow trust Members & 0.1883 \\
\hline & & knowledge of business & 0.1854 \\
\hline & & business skills & 0.0817 \\
\hline & & innovation & 0.0425 \\
\hline
\end{tabular}




\section{CONCLUSIONS}

The survey results revealed that each technology component has a value as follows: technoware component of the operation of the order is a factor (0.2889), quality of raw materials (0.2770), improvement of production efficiency (0.1894), the fulfillment of production capacity (0.1717), technology adoption (0.0489) and resource technologies (0.0242). Components of the order value is organoware environmental management factor (0.6267), marketing management (0.2797) and production management (0.0936). Components infoware order value is a factor of production records $(0.6267)$, the promotion of products $(0.2797)$ and documentation effort (0.0936). Humanware component order is the motivation factor $(0.5022)$, the trust fellow members (0.1883), knowledge manager (0.1854), the management skills (0.0817) and innovation (0, 0425).

All efforts to improve the quality of small-scale food industry cluster is in need of the role of government. Since the development of the cluster is affected by government policies, particularly those related to the cost of production. In addition, the low bargaining power producers caused by the marketing monopoly will lower the rate of profit.

\section{ACKNOWLEDGMENT}

Acknowledgements pronounced in West Sumatra Provincial Government, particularly the Department of Agriculture for their support in the implementation of this research.

\section{REFERENCES}

[1] Agustiningrum, E.P. 2010. Ekspektasi Peran Klaster Batik Pekalongan dalam Pengembangan Klaster Regional SAMPAN (Sapta Mitra Pantura). Tesis pada Program Pascasarjana Magister Teknik Pembangunan Wilayah dan Kota. Universitas Diponegoro, Semarang.

[2] Clark, J.R., Dwight R. Lee. 2006. Freedom, Entrepreneurship and Economic Progress. Journal of Entrepreneurship, USA, Vol. 15, No. 1, 1-17 (2006).

[3] Departemen Perindustrian Republik Indonesia. 2009. Peta Panduan (Road map) Pengembangan Klaster Industri Proritas Industri Kecil dan Menengah Tertent Tahun 2014 - 2014.

[4] Devanath T. 2008. Role of Technological Innovations for Competitiveness and Entrepreneurship. Journal of Entrepreneurship India, Vol. 17, No. 2, 103-115 (2008).

[5] Dinas Pertanian Tanaman Pangan Propinsi Sumatera Barat. 2013. Profil Kelompok UP3HP di Sumatera Barat. Dinas Pertanian Tanaman Pangan Sumatera Barat, Padang.

[6] Lestari, I., dan Budisantoso Wirjodirdjo. 2010. Analisis Kesejahteraan Pelaku Industri Pengolahan Ikan pada Komunitas Klaster Masyarakat Nelayan Pesisir : Sebuah Pendekatan Dinamika Sistem. Institut Teknologi Sepuluh Nopember (ITS), Surabaya.

[7] Marijan, K. 2005. Mengembangkan Industri Kecil Menengah melalui Pendekatan Kluster. Fakultas Ilmu Sosial dan Politik Universitas Airlangga, Surabaya.

[8] Mulyono, S. 1996. Teori Pengambilan Keputusan. Lembaga Penerbit Fakultas Ekonomi Universsitas Indonesia

[9] Nu'man, A.H. 2008. Kebijakan Pengembangan Industri Kecil Menengah Sebagai Suatu Strategi Peningkatan Daya Saing di Era Perdagangan Bebas. Pustaka Pusat ITB, Bandung.

[10] Porter, M.E. 2010a. High Value Vegetables in Tanzania - The seeds of a Conrtitive Cluster. HBS Microeconomics of Competitiveness, Tanzania.

[11] Porter, M.E. 2010b. The Mexican Chocolate Cluster. The Microeconomics of Competitiveness. Harvard University, USA.Porter, M.E. 2011. Creating Shared Value : Redefining Capitalsm and the Role of the Corporation in Society. Harvard Business School, USA. 